\title{
Managing Pastoralism and Water Rights in the Upper West Region of Ghana: A Blame Game Among Actors
}

\author{
Nicholas Fielmua ${ }^{1}$, Robinson D. Boye Bandie ${ }^{1} \&$ Marshall K. Ziemah ${ }^{1}$ \\ ${ }^{1}$ University for Development Studies, Wa Campus, Ghana \\ Correspondence: Nicholas Fielmua, University for Development Studies, ICEIR, Wa Campus, Ghana. Tel: \\ 233-243-255-001. E-mail:nfielmua@yahoo.com
}

Received: October 14, $2013 \quad$ Accepted: December 24, $2013 \quad$ Online Published: January 8, 2014
$\begin{aligned} & \text { doi:10.5539/jsd.v7n1p72 } \\ & \text { URL: http://dx.doi.org/10.5539/jsd.v7n1p72 }\end{aligned}$

This research was partially funded by CARE International, a Non-Governmental Organization and the Research Team is grateful to them. We equally acknowledge the cooperation that the various actors granted us during the research.

\begin{abstract}
This paper examines the interaction among actors in pastoral practices and right to access water in the Upper West Region of Ghana. Water rights, the environment and pastoral practices have been the main issues of discussion in many countries, and Ghana in particular. The focus has always been the negative effects of pastoral activities on environmental resources with less attention on the positive side of it. This paper presents findings on the relationship among various actors (government agencies, community members, herdsmen, livestock owners, and chiefs) in managing pastoral practices. Focus group discussions and key informant interviews were held with the various actors to understand their relationship with one another on pastoral practices and water rights in the Upper West Region of Ghana. The study revealed that the various actors perceive one another as the cause of weak management of pastoral practices in the area and as such blame each other in pastoral practices. This attitude (blame game) has affected the activities of all the actors with serious implications on social and food insecurity in the area.
\end{abstract}

Keywords: pastoralism, water rights, blame game, herdsmen

\section{Introduction}

The interplay of water rights, the environment and pastoral practices has been a central issue of discussion in many countries. The central issue of discussion has been on the negative dimension of pastoral activities on environmental resources. As such, pastoralists have borne the greater part of the blame for environmental degradation, and many policy makers have been compelled to address its related issues (Katjiua \& Ward, 2007; McCabe, 1990; Thébaud \& Batterbury, 2001). Thébaud and Batterbury (2001) argued that the conditions that pastoral communities face are related to the negative discourse that is being discussed about pastoralism within development policy by government officials. Thus, to view pastoralism with negative lenses is a common feature of pastoral areas in sub-Sahara Africa, and perhaps a lack of adequate communication among the actors. Hence, Adger et al. (2005) maintained that access to information and its proper communication is important in minimizing conflict over environmental issues. This can be the result of high rate of development intervention failure, often due to misconceptions by decision-makers and planners of local resource management and livelihood systems (Nori et al., 2008). But Robinson and Berkes (2011) hold the view that policy makers and development programmes do not adequately acknowledge the complexity of pastoral system because many do not have the requisite framework to understand pastoralism and plan accordingly.

For some decades, some researchers held the view that pastoralism is less harmful to the environment (Hogg, 1987). On the contrary, the pastoralists equally seek to maintain a balance between pastures, livestock and people (Nori et al., 2008). Recently, it was argued that climate change increases the risk of pushing farmers to cultivate on marginal lands, and pastoralists are better placed to reclaim such areas (Nori et al., 2008). Again, pastoral areas are not suited to widespread agriculture or more intensive or sedentary forms of animal husbandry, and as such, investing in pastoralism has low opportunity costs (Hesse \& MacGregor, 2006). Pastoralism offers 
the most cost-effective way of supporting relatively large populations in these areas and at minimal environmental cost. These arguments support the need and relevance of pastoralism and that the neglect of pastoralism carries huge potential costs, since poverty, environmental degradation and conflict are likely to increase due to local people losing their livelihood base and struggle for survival. This is because extensive pastoral production is practiced on $25 \%$ of the global land area, from the dry lands of Africa $(66 \%$ of the total continent land area) and the Arabian Peninsula, to the highlands of Asia and Latin America Alive (2006) cited in (Nori et al., 2008).

Again, livestock possession is a central element of one's socio-economic status and religious life, and without livestock, one is lost, as one will not have social status, power and cannot support a family (Bayer et al., 2001; Bogale \& Korf, 2009; Köhler-Rollefson, 2001). Livestock serves as food and income security because they are able to withstand fluctuating weather patterns than crop (Bogale \& Korf, 2009). Therefore, livestock forms an integral part of social life and ideological values that guarantee the survival of individuals and the continuity of institutions (Fabusoro, 2009; Katjiua \& Ward, 2007; Omosa, 2005). To pastoralists, livestock are insurance as they provide social links through bride price, inheritance and as ritual objects (Omosa, 2005). Despite the argument for pastoralism as a sustainable livelihood, and in some countries, institutional reform in support of pastoral mobility (e.g. the pastoral laws in Mauritania and Mali), globally governments still have a very negative perception of mobile pastoral systems (Nori et al., 2008; Thébaud \& Batterbury, 2001). On the other hand, the poorer households see the large owners as the only available animal banks to which they might turn as lenders of last resort either for assistance in rebuilding their own cattle numbers or for subsistence animals or even merely for employment as herders (Livingstone, 1986).

Notwithstanding the argument about the activities of pastoralists, access to natural resources (water, pastures, land) is a major element of their livelihoods (Gomes, 2006). Besides the fact that access to natural resources is tied to property rights, pastoralists are required to move to enable them access these resources. But the issue at stake with property rights is that, they are relational in several spheres because they define rights and duties of an individual vis-à-vis a collective (Bromley, 1991). In pastoralist societies, many resources are based on communal property rights, meaning those resources are used by a group of users, normally the (sub) clan, who holds customary rights over a specified territory (Beyene \& Korf, 2012). Secondary user rights exist in territories held by other clans and as such secondary access and user rights are subject to negotiation with the primary rights holders (Beyene \& Korf, 2012).

The mobile, transhumant mode of livestock keeping demands a flexible tenure regime based on non-exclusive use rights to pasture and water resources (Beyene \& Korf, 2012; Cousins, 1996; Scoones \& Graham, 1994). With water sources such as wells and boreholes, user rules are quite differentiated, but there are some commonalities across different locations and ethnic groups. In all sites, the usual norm in defining watering priorities is "first-come, first serve" - but users with a small number of livestock usually get priority over large livestock owners, because they require relatively little time to water their animals (Beyene \& Korf, 2012). They however noted that the right to pasture is not necessarily linked with the right to access water.

In the Upper West Region of Ghana, scarcity of water especially in the dry season has intensified the debate on pastoralism and their effects on water resources. Although there were several measures by the Upper West Regional Coordinating Council to eject pastoralists as a way of resolving the rampant conflicts between pastoralists and farmers (Tonah, 2002), pastoralists are still residing in the Region and the conflict between them and other actors remains a challenge. Transhumance is common in the Region where transhumant pastoralists move into the region especially along the Black Volta in the dry reason and return to Burkina Faso and Mali in the rainy season. Pastoralism in the region has two dimensions. The first dimension entails the herdsmen (mostly Fulani) who take care of natives' livestock. The second dimension is a situation where the herdsmen are the real owners of the livestock. The first dimension implies that natives are involved in pastoralism. In this category, pastoralists sometimes combine their livestock with those of the indigenous livestock owners. It has been established that there is mistrust in the relationship between livestock owners and herdsmen. While livestock owners blame herdsmen on cattle rustling, the herdsmen also insist that livestock owners intentionally inflate their cattle losses in order to win sympathy from colleague livestock owners (Tonah, 2002). Besides the conflict between the herdsmen and the livestock owners, the increasing activities of pastoralism, coupled with increased human population has resulted in environmental degradation, destruction of crops and unhealthy competition for natural resources (Tonah, 2003).

Tonah (2003) further established that various governments in Ghana have been generally hostile to the Fulani pastoralists. While government policy documents and policy makers appear to be hostile towards pastoralism, Tonah (2002) found that local government officials tolerate the Fulani for fear of displeasing the chiefs and some 
prominent persons who are livestock owners. Besides this, it has been established in this study that some of the livestock owners (herded by Fulani) occupy government positions in decision making. Interestingly, the local government in the Upper West Region set up a task force to regulate the activities of pastoralism and prosecute chiefs who allocate land to these pastoralists. The chiefs on the other hand view this decision as local government usurping their role by deciding who they (chiefs) should allocate land to (Tonah, 2002). The question is: who is to be blamed for the externalities of pastoralism in our society? Blaming is as old as the beginning of the world.

Blaming is a self-defense mechanism and people react (personally, in a group, or as a corporation) when they are under pressure, when they make mistakes, when they are put into "uncomfortable" situations, or when they are attacked (Hein, 1998). They react in two basic ways (with variations) - they fight back (attack) or they withdraw. In most instances, blaming is used to deflect a problem, incident, situation and/or attention away from yourself (Hein, 1998). Blaming one another especially in environmental degradation has been attributed to pastoralists (See for instance Katjiua \& Ward, 2007; McCabe, 1990; Thébaud \& Batterbury, 2001). However, in the Sahelian countries, economic, institutional and social factors are equally to be blamed for the changes in the environment since these factors equally influence and perhaps destabilize the pastoralist activities (Thébaud \& Batterbury, 2001). The institutional and social blame game has been extended to disaster incidents. For instance, when the Hurricane Katrina hit Gulf Shore in 2005, the black race blamed the government for not responding to their plight and attributed it to their race (Sweeney, 2006). Although the government wanted to avoid this blame, the pictures of the devastation showed that the most affected were the poor black due to their location (Sweeney, 2006). The fundamental issue about blame is that someone or group of persons feel things are going worse and it could have been avoided if other people acted differently, although in some instances, individuals blame themselves for avoidable loss or harm (Hood, 2010).

\subsection{Concept of Pastoralism}

Various views have been expressed on pastoralism. In some instances, pastoralists were viewed as primitive, violent and hostile towards change (Gomes, 2006). They have an emotional attachment to their livestock, lack rules and regulations to manage their resources, they are attached to the traditional way of life and they lack in national loyalty because of their cross border movements (Hendrickson et al., 1998; Omosa, 2005). But what exactly is pastoralism, a term that has received much criticism within the academic, policy and government? According to Omosa (2005), pastoralism is a production strategy in which people raise herd animals as a means to earn a livelihood. It relies on the availability of water, pastures and labour to thrive, and as such they move to new places in search of fodder and water for their herds (Dwyer \& Istomin, 2008; Omosa, 2005). Therefore, pastoralism, regardless of the extent to which it contributes to the household economy, refers to any predominantly livestock-based production system that is mainly extensive in nature and uses some form of mobility of livestock.

With a few notable exceptions (for example Somalia and Mongolia), pastoralists are usually a minority in their countries occupying marginal land along national borders, and ruled by a political elite often representing an agricultural majority who live in higher rainfall zones (Omosa, 2005). According to Nori et al. (2008), pastoral groups typically inhabit areas where scarce resources and extreme climatic conditions limit options for alternative land use and livelihood systems. Based on the above, pastoralists are people who keep animals on natural graze and for whom animal breeding is economically and culturally dominant, or simply put, they are livestock herders (Köhler-Rollefson, 2001; Omosa, 2005). Mobile pastoralists are a large and significant minority, and often ethnic minority. The issue of minority and majority are tied to power relationships (Omosa, 2005).

Movement of animals and people is a core characteristic of pastoralism (Dwyer \& Istomin, 2008). Mobility is an ecological and economic necessity because it allows pastoralist to access marketing opportunities, allows access to a range of pastures and allows pastoralists to avoid diseases in some locations (Nori et al., 2008). Therefore, the movement is also affected by ecological/environmental and non-ecological factors (Bogale \& Korf, 2009; Dwyer \& Istomin, 2008). For instance, rivers are mostly dependent on the quantity and supply of rain water (Entsua-Mensah, 2001). The rainfall variability has also affected the volume of water in the rivers. Hence, Oba and Lusigi concluded that:

"In order to cope with the varying rainfall and forage distribution, both nomads and their animals must possess a high degree of mobility. Two aspects of mobility should be recognized. Resource exploitation mobility is undertaken in response to unpredictable forage and water availability. Escape mobility involves 
long distance migration to escape drought conditions. In either case, the primary objective is usually to maximize livestock survival" (Oba \& Lusigi, 1987:22).

In that regard, Dwyer and Istomin (2008) added that nomadic movement is an intellectual response of herdsman to the behavior of herds, thus making pastoralism a dynamic phenomenon. It has been argued that governments and other actors outside the core realm of pastoralism failed to understand the dynamics of pastoralism (Nori et al., 2008). Hence, for so many years, the literature presents pastoralism as environmentally destructive. This has compelled researchers and academicians to devise theories to explain the behavior of pastoralists.

Interestingly, the famous theoretical framework of Garret Hardin, 'tragedy of the commons' provided an opportunity for those outside pastoralism to perceive it as an irrational land use (Nori et al., 2008). They noted that despite the fact that the theory wrongly assumed pastoral resource ownership as open access, the theory succeeded in perpetuating the negative legends of pastoralism (Nori et al., 2008). Again, the timing of Hardin's article provided the anti-nomadic to take an entrenched position that pastoralism was more destructive. The article was published immediately before the Sahelian drought emerged, in which livestock died and the environment destroyed (McCabe, 1990). The argument of the theory from a livestock and range perspective is summarized as follows:

A herdsman puts his animals on a pasture that he uses in common with other herdsmen. Even though there are signs that the condition of the pasture will worsen with additional stocking, it is only rational for each herdsman to add more animals to his herd because he gains the full benefits of each additional animal while sharing the costs of overgrazing with the other herdsmen. The positive utility to the individual herdsman of adding an extra animal is +1 ; the negative utility is but a fraction of -1 . MacCay and Acheson (1987), cited in (McCabe, 1990:83).

This implies that when a resource is physically and legally accessible to more than one user, then the users compete for a greater part of the resource and in most instances, to the detriment of the resource and themselves (Ciriacy-Wantrup \& Bishop, 1975). This suggests that common ownership of pastures leads to over-grazing and over exploitation of resources (Tonah, 2002). This theory maintains that there is open access to pastures and the findings of Tonah (2002), that right to grazing is open to both indigenes and migrants in Northern Ghana support Hardin's model. In another study, Tonah (2003) found that local livestock owners who are themselves the herdsmen accused the Fulani herdsmen of over exploiting the scarce resources because they graze both day and night. Despite the evidence of overexploitation of open access resources, Feeny et al. (1990) earlier argued that Hardin's model overlooks the role of institutions in regulating access to pastures and the complex interaction of actors in a common situation is equally relevant. This has to be analysed within the context of property rights.

\subsection{Water Right within the Context of Property Rights}

Water rights form part of the broader property rights. Property rights refer to the relationship among various stakeholders with regard to things such as natural resources (Agrawal \& Ostrom, 2001). Property rights do not automatically suggest a sole authority to the control of the resource, but that rights are differentiated according to specific users or other bundle of rights that may not entail absolute control over the resource (Beyene \& Korf, 2012; Hagedorn et al., 2012). These bundle of rights include the following: the rights to use the asset, including access and withdrawal, i.e. the right to enter a physical area and obtain the resource; the right to appropriate the return from the asset, including earning income from it; the right to change its form or transform the resource, substance, and location, including decision-making rights such as management and exclusion; and alienation, i.e. the right to transfer rights to others, either by inheritance, sale, or gift (Agrawal \& Ostrom, 2001; Hagedorn et al., 2012; Meinzen-Dick \& Nkonya, 2005; Williamson, 1993).

Similar to property rights, water rights are not homogeneous but entail a bundle of rights held by different actors in water (Meinzen-Dick \& Nkonya, 2005). Mostly, the more variable the resource, the more flexible the property rights that are developed over it. Water rights are particularly fluid, changing by season and year, depending on the availability of the resource and its demand (Livingstone, 1986). Water in its visible and natural form - as sea, rivers or lakes - cannot be privately owned. It is also unclear whether it is public property. In some societies, surface water is public property and vested in the government. For instance, in Tanzania, waters are vested in the United Republic of Tanzania and all citizens have equal rights to access and use of the nation's water resources (Kabudi, 2005). These provisions imply that non-citizens access to water resources may be limited and are granted under certain conditions. This makes it important to define rights over resources, such as water because it minimises conflict especially during scarcity (Meinzen-Dick \& Nkonya, 2005). Similarly, in Ghana, the property right and control of all water resources is vested in the President on behalf of, and in trust for the people of Ghana (Water Resources Commission, 1996). Although property rights in most instances are vested in the 
state, in the case of water, customary law, often backed by rules and norms, may apply (Meinzen-Dick \& Nkonya, 2005).

Within the Ghanaian context, in some locations, water resources belong to the king and he holds it in trust for his people while in other communities, water is said to be 'ownerless' (Mensah, 1999:9). Generally, a private person will never be allowed to purchase or own a surface source of water (Mensah, 1999). What then constitutes water rights? Various interpretations have been put forward to explain water rights. A plethora of authors share the following attributes of water rights. Accordingly, water rights are socially recognized claims to water, which may be composed of a bundle of rights to: access, consume, exclude, manage and transfer or divert public water and put to beneficial use (Bruns, 2007; Dennis \& Arriens, 2005). For others, water rights is a formal or informal entitlement which is conferred on a holder the right to take and use water subject to the terms and conditions of the grant (Bird et al., 2007; Burchi \& D'Andrea, 2003). These explanations suggest that water rights are characterized based on quantity, duration and ownership, usage, source, timing and conditionality (Bird et al., 2007). Table 1 presents an explanation of these attributes.

Table 1. Attributes of water rights

\begin{tabular}{|c|c|}
\hline Attribute & Description \\
\hline Quantity & $\begin{array}{l}\text { The amount of water (volume) the holder of the right may abstract, or the amount of } \\
\text { waste (volume / concentration or load) that the holder of the right may discharge. }\end{array}$ \\
\hline Source & The specific resource and location from which the right is awarded. \\
\hline Timing & $\begin{array}{l}\text { Restrictions on the time that the right applies, i.e. times that the volume may be } \\
\text { abstracted or time that the waste may be discharged. }\end{array}$ \\
\hline Conditionality & $\begin{array}{l}\text { The conditions of use, particularly in terms of quantity and quality. Some rights are } \\
\text { absolute }-100 \% \text { guarantee of a certain quantity and quality, while other rights have } \\
\text { variable assurance of supply and quality depending on the available resource. Other } \\
\text { conditions can include any 'Hands Off' flow requirements to protect minimum } \\
\text { environmental flows. }\end{array}$ \\
\hline $\begin{array}{l}\text { Duration and } \\
\text { ownership }\end{array}$ & $\begin{array}{l}\text { The duration for which the holder is entitled to the rights conferred. Some rights are } \\
\text { permanent while others expire after a period of time. }\end{array}$ \\
\hline $\begin{array}{l}\text { Security and } \\
\text { enforcement }\end{array}$ & $\begin{array}{l}\text { Details of the administrative body that has the legal mandate to award the right, } \\
\text { including the extent of that mandate. Important here is the extent to which the rights } \\
\text { conferred can be guaranteed to the right holders, what measures are taken if the rights } \\
\text { cannot be fulfilled and the compensation received if the rights cannot be fulfilled (or } \\
\text { the right is removed). }\end{array}$ \\
\hline Use & The specific use for which the water is abstracted. \\
\hline
\end{tabular}
Source: WWF (2007) cited in Bird et al. (2007:15-16).

In most instances, especially within pastoralism, the rights holders are limited to use certain amounts of water rather than the right to the ownership of the water resource itself. Many systems may include provisions for penalizing the non-use of allocated resources (Dennis \& Arriens, 2005). The basic underlying rationale for the establishment of water rights, from a policy perspective, is that a clear definition of who is entitled to use a certain amount of water, with the specification on when and where this is possible, will reduce uncertainty and conflicts (Molle, 2004). The establishment of water rights especially amidst pastoralism will definitely consider who uses how much water, the types of uses allowed, and when those waters can be used (Meinzen-Dick \& Nkonya, 2005) and this is where the blame game sets in. This paper therefore seeks to understand the relationship among the various actors in pastoralism along the Black Volta Basin of the Upper West Region in Ghana. The focus was on the Black Volta Basin because the activities of pastoralists are much felt in this area.

\section{The Research Approach}

The research adopted a case study approach. This approach allows researchers to investigate a contemporary phenomenon, such as pastoralism, within its real-life context (Yin, 1994, 2003). In terms of its epistemological stance, qualitative design was adopted and the main tools used in collecting data include Focus Group 
Discussion (FGD) and key informant interviews. Four categories of actors were targeted in this study. These actors were chiefs and elders, herdsmen, livestock owners and government institutions (the District Assembly and the Ministry of Food and Agriculture). In the Upper West Region, these actors constitute the core actors in pastoralism and water rights. Focus Group Discussions were held with these categories of actors in ten communities. The ten communities were divided into two groups, comprising five communities in each group. The grouping of the communities was based on their geographical location. In each group of communities, the first category of FGD was held with chiefs and elders in the area. The aim was to gather their experience with livestock owners, herdsmen, the District Assembly and the Ministry of Food and Agricultural (MOFA) as far as pastoralism and water rights are concerned. The second category of FGD was held with the livestock owners to seek their views on pastoralism and water rights in the area. The third category of FGD was held with the herdsmen. Within the Ministry of Food and Agriculture, there are Agricultural Extension Agents and Veterinary Officers who work directly with farmers and herdsmen. Hence the fourth FGD was held with officers of the MOFA who work in these communities. Again in each District, there is a District Water and Sanitation Team that is responsible for water and sanitation related issues. The final FGD was held with members of this team. Besides these FGDs, key informant interviews were also held with the District Director of MOFA, and the District Coordinating Director. In each of the ten communities, key informant interviews were held with the community level women leader (Magazie). Therefore, a total of eight FGDs and twelve key informant interviews were held to collect the data. Although Pastoralism refers to subsistence, based primarily on domesticated animal production, the focus of this study was on cattle production. This is because cattle production influences the environment and water usage than other domesticated animals in the Region. Moreover, cattle production involves hiring of Fulani herdsmen and this equally has social implications. The Focus Group Discussions and key informant interviews were recorded using digital recorders. These were transcribed and analyzed manually.

\subsection{Limitations of the Study}

The study was carried out in the dry season, a season that did not provide the team the opportunity to observe destroyed crops by herds as alleged by the farmers. Moreover, claims that women were raped by Fulani herdsmen could not be validated by the research team from the affected women. The relatives of the affected women were not willing to grant access to the victims. The Research Team respects the privacy of the respondents and the victims of rape. However, discussions with the Traditional Authorities also indicated that they have arbitrated rape cases involving Fulani herdsmen.

\section{Research Findings}

\subsection{Pastoral System in the Upper West Region}

In pastoralism, water constitutes an essential resource. As a result mobility pattern takes into account the availability of water and the right to use it. In the Upper West Region, the pastoralists/herdsmen move along the Black Volta Basin where the river and its tributaries provide water for the animals on perennial basis. However, where the livestock belong to the natives, settled pastoralism is practiced. This is a system where the herdsmen stay at one place and move the livestock around for pastures and water. It is on rare cases that the herdsmen and the livestock relocate from where the livestock owners (natives) stay. Therefore, in the Upper West Region pastoralism has two dimensions. The first dimension entails the herdsmen (mostly Fulani) who take care of natives' livestock. These are the hired pastoralists. With this system, the livestock owners and the herdsmen usually come to an agreement in terms of compensation for herding the livestock. The extent of movement with this system is subject to the wish of the livestock owner. The second dimension is a situation where the herdsmen are the real owners of the livestock. With this system, it is sometimes necessary to move the herds and at times, the household continually in search of fresh pastures and water, making this a wandering, nomadic way of life. The ultimate aim is to search for fresh pastures and water.

\subsection{The Role of the Actors}

In Ghana, the Water Resources Commission is responsible for the regulation and management of the utilization of water resources. At the district level, the District Water and Sanitation Team (DWST) is established by each DA to function as the technical wing of the Assembly in providing and guiding communities in the management of water and sanitation related services. The Ministry of Food and Agriculture at the district level is responsible for all agriculture related activities including livestock. The veterinary division is to ensure health safety of livestock, by providing veterinary services. The District Department of MOFA is to advice the District Assembly on agriculture related issues within its jurisdiction. At the community levels, the chiefs and the landlords (Tendamba) are the core institutions to grant permission to settle in a particular area. Permission of livestock owners to receive herdsmen is granted by the chiefs, in consultation with relevant landlords for the piece of land 
where the pastoralists will be settled. Management of water sources (specifically, borehole with pump, community hand dug well with or without pump) is vested in the water and sanitation committee of the area. These committees are established by the community with the approval and authority of the District Assembly. The committees in consultation with the community members establish guidelines for the usage of water by human and livestock at the water sources that are under their control.

\subsection{Interaction Among Actors and the Blame Game}

In the Upper West Region, land at the community level is mainly family/clan land and the landlords are the custodians who manage it on behave of the family/clan members. The chiefs are the general overseers of the community. The chiefs and landlords are responsible for permitting the arrival and settling of herdsmen within their jurisdiction. The study revealed that the Traditional Authority comprising chiefs and elders including the Tendamba usually consent to the settlement of pastoralists. In a situation where natives own livestock and have to recruit herdsmen (mostly Fulani) to herd the cattle, the Traditional Authorities are well informed prior to the arrival of the herdsmen. However, discussion with the chiefs and elders revealed that livestock owners sometimes engage herdsmen without their knowledge. In such instances, the herdsmen respect only the livestock owners and view them as above anybody else in the community. According to the chiefs and elders, there are instances of non-cordial relationship between chiefs and herdsmen because the chiefs judge and impose sanctions on them (herdsmen) when they err.

Interaction with livestock owners indicated that chiefs play an important role in settling disputes in the communities, especially between them and the herdsmen. In cases of missing livestock, it is the chiefs and sometimes the Tendamba who help in locating the missing livestock. This is done by beating gong-gong to announce to the general public and at times issue of threats (invoking evil spirit on the thieves). The livestock owners rather have major concerns with the herdsmen and some community members. They indicated that many of the herdsmen are not trustworthy and there are frequent misunderstandings between herdsmen and livestock owners. According to the livestock owners, some community members demonstrate jealousy and often initiate dispute with the herdsmen in various forms including farming very close to the kraals.

The Assembly and MOFA indicated that chiefs are reluctant to cooperate with other stakeholders in enforcing bye-laws. They added that herdsmen settle in communities without the knowledge of the District Assembly (DA) or MOFA. There is very little transparency in interaction among chiefs, Assembly members in various electoral areas, and the herdsmen. The DA and the MOFA are suspicious of conspiracy in settling herdsmen illegally. This has affected the tax base of the District Assembly, because the livestock owners and herdsmen do not register with the DA/MOFA. This adversely affects the internal revenue generation of the DA. The Nadowli District Assembly and the MOFA indicated that MOFA has inadequate technical officers to actually render technical services to pastoralists in the area. This has resulted in loss of animals through diseases. They further revealed that there are rules and regulations governing the operations of pastoralism. However, weak cooperation and commitment of other actors such as chiefs, Ministry of Food and Agriculture (MOFA) and livestock owners has hampered the enforcement of the rules and regulations.

The interaction with the herdsmen as regard their relationship with the other actors in pastoralism revealed that they (herdsmen) have deep knowledge on the causes of environmental degradation. Although they acknowledged that pastoralism has adverse effects on the environment, the herdsmen indicated that they are not the sole cause of environmental problems, because there are equally serious activities outside the realm of herdsmen that affect the environment. For instance, according to the herdsmen, environmentally, charcoal production is entirely unsustainable and depletes forest and rangeland resources. Rangeland degradation is already evident with increased soil erosion from wind and runoff. In addition to the trees burnt for charcoal, other plants and shrubs are used as fuel, thus reducing the availability of natural resources in general. As a result some species are becoming extinct and wildlife animals are no longer seen in such great numbers.

While the herdsmen acknowledged their shortfalls in pastoralism, they are worried about the societal stereotype. According to the herdsmen, the other actors see them as the root cause of all societal problems, including poverty. They were however of the view that all of them are to be collectively blamed because there are equally lapses in the activities of local government, chiefs and the livestock owners as far as pastoralism is concerned. A member of the focus group has this to say: "if you cut my body, you will see blood and if I also cut your body, I will see blood. This means that we have one thing in common, i.e. we are all human beings. But the chiefs, community members and government handle us as if we are not human beings". He added that we all have conscience and it is inhuman to behave in a manner that will hurt a fellow human or cause him/her to lose a source of livelihood. This implies that the herdsmen link their hostile relation with other stakeholders in 
pastoralism to they (herdsmen) being minority and non-natives rather than just the alleged negative activities of herdsmen. They further revealed that some of the chiefs are disrespectful. They admitted that there are often conflicts between them and the livestock owners and attributed it to the livestock owner's failure to honor their obligations to them in terms of feeding and payment for their services.

\subsection{Problems Associated With the Activities of Herdsmen}

The various actors, including the herdsmen, have identified and discussed development problems that are associated with the activities of herdsmen. According to the chiefs and elders, the activities of the herdsmen have resulted in overgrazing leading to land degradation, and destruction of crops and economic trees. The herdsmen often engage in bush burning for the purpose of allowing grass to germinate resulting in soil degradation and this has adversely affected crop production. They further indicated that there have been reported cases of women and girls who have been raped by the herdsmen. The livestock owners also shared their experience on the activities of the herdsmen. Accordingly, some of the herdsmen are dishonest and thieves, and at times very unpredictable in their behaviors. In instances where the herdsmen own some of the livestock, it is the indigenous livestock owners that lose their cattle to theft and disease. A member of a focus group discussion said that a Fulani man's cow never dies or is stolen. Rather it is always the indigenous livestock owners' cows that are affected by theft and disease. They further indicated that there are instances where they suspect foul play when a herdsman reports of a missing cow. These happenings have often resulted in misunderstanding between the livestock owners and the herdsmen.

According to the livestock owners, they receive so many complaints from community members about their herdsmen activities such as allowing livestock to destroy crops, and other social vices. The herdsmen acknowledged that at times their livestock destroy crops but added that it is not at the will of the herdsmen. Again due to limited water sources, they (herdsmen) sometimes engage in indiscriminate watering of animals, hence animals share water sources with human beings. On the other hand, certain actions and/or inactions of herdsmen also pose a problem to the smooth operation of pastoralism as a source of livelihood. According to the actors, including MOFA, inadequate veterinary service has affected the quality and the quantity of livestock in the area, which further affects the quantity and the quality of food and dairy products in the area. Moreover, pastoralism is the main source of livelihood for the pastoralists and stealing of livestock has resulted in reduction in animal stock and this has contributed to the current hunger and poverty, especially among those affected households. According to the chiefs and elders, although the MOFA is supportive in providing technical advice and the treatment of animals, they are faced with limited field personel and usually run-out of drugs for livestock.

\subsection{Access to Water}

Discussions with the actors revealed that there are generally no rules and regulations in watering animals along the Black Volta and its tributaries. It is the belief of the people along the Black Volta River that water from the river is nature's property. As one chief mentioned, "Water is a gift from God, and for that matter whatever God has created, including human beings and animals, should never be deprived of water". The herdsmen travel along the Black Volta and its tributaries to water their animals but as the communities engage in dry season gardening, the herdsmen are to ensure that the herds do not destroy the crops/vegetables, but in most instances they fail to control the herds. On the other hand, watering of animals at stand point sources (Hand dug wells, boreholes with hand pumps) is restricted. Pastoralists who do not belong to a particular community and/or do not contribute to the maintenance of the stand point sources are restricted from watering their animals at such stand point sources. In the case of pastoralists who contribute financially to the maintenance of the point sources, they are allowed to water their animals on first- come- first- serve basis. According to women leaders, when the herds come to water, women and children who are there to draw water often fetch before the herdsmen water their herds. Depending on the number of people at the water source, the herds are allowed to water after so many people have fetched. When the herds are being watered, then the people are required to wait. This has led to long waiting time (about 85 minutes) for drawing water in the dry season. There are major concerns in accessing water for domestic use and watering of livestock. All the actors indicated that with increasing human and livestock population, there is pressure on the existing water sources. In some communities, some households use the water from rivers for laundry and gardening. But these water sources are often polluted by animals and some human activities, such as fishing. 


\section{Discussion}

It has been established that the practice of pastoralism has not changed significantly, likewise the perception of other stakeholders about their (pastoralists) activities. Unlike other properties, the mobility of surface water such as rivers, coupled with the difficulty in defining what quantity of water to be used by who and for what purpose, makes it difficult to enforce rights (Meinzen-Dick \& Nkonya, 2005). Besides this, the natives view water as a treasure of nature and what nature has given should be accessible to everybody and anybody at any time. Therefore, at the community level, there is a strong cultural norm of non-exclusion, which prohibits the exclusion of people from access to water for primary uses (including livestock watering). Similarly, the local perception of water as a common good also manifests in public livestock watering rights and the right to request water from another person, who is then obliged to provide water for drinking (Eguavoen \& Spalthoff, 2008).

All the actors acknowledged that livestock destroy crops. This supports the findings of Tonah (2003) and Tonah (2002). Tonah (2002) further noted that destruction of crops and the consequential conflict between farmers and pastoralists dates back to colonial period when shifting cultivation was practiced and livestock movement from the north to the livestock market in the middle and southern Ghana. This kind of movement resulted in crop destruction, a phenomenon that is still reported to date. With the presence of climate change and its impact on food production, the MOFA indicated that the destruction of crops by livestock has worsened food insecurity in the area.

Whereas, there is unlimited access to water along the Black Volta River, the situation is different with regards to stand point sources (hand dug wells, boreholes with hand pumps). These sources of water supply require routine maintenance and therefore have cost implications. The discussants indicated that in the dry season where the streams are dried up, both animals and human beings compete for water from various sources. The practice is first come first serve. Similar to the findings of Beyene and Korf (2012), those with small number of livestock have the advantage of watering their animals first before those with large number of livestock. When it comes to payment for operation and maintenance, the herdsmen and the livestock owners indicated that those with large number of livestock pay more than those with small number. Generally, households that water their livestock (cattle) at the stand point sources pay higher than those who do not water livestock at all at the stand point sources. Access to water drawn from well/borehole with hand pump and rivers along the Black Volta Basin is similar to pastoralism in Kenya where McCabe (1990) observed that access to water is restricted when drawn from a well and not restricted when drawn from rivers/pools. Pastoralists in Niger and part of Northern Ghana often secure watering rights and rights to land for pasturing either through an animal loan or cash payment (See Thébaud \& Batterbury, 2001; Tonah, 2002). However, specifically in the Region, payment of tax and water fees remains a challenge. Whereas pastoralists blame government officials of demanding higher taxes and livestock owners of not living up to the initial agreements, government officials also blame pastoralists of tax evasion, although the herds access water and pastures. The livestock owners also blame pastoralists for cattle rustling and this was also established by Tonah (2003).

According to the women leaders, the watering of animals has worsened the problem of long waiting time at the point sources. On the other hand, livestock owners complain that they pay higher than other users yet they do not have the liberty to water their livestock at will. This is a potential source of conflict over right to use water for domestic purposes and watering of livestock. The study confirms the findings of Beyene and Korf (2012), that the right to pasture is not necessarily linked with the right to access water points, but generally, it is granted in combination, because exclusion from water while granting access rights to pastures would make enforcement costs prohibitive and would likely create disputes at water points.

It has been established that conflicts are not only linked to resource scarcity but to non-payment of tariffs, theft cases, crop destruction, and social vices that are alleged to have been committed by the herdsmen (Bogale \& Korf, 2009). According to Tonah (2002), in some parts of Northern Ghana, some of the hired herdsmen are not often directly remunerated. They depend on the sale of milk as source of income for other household needs. However, during the dry season, low milk production compelled herdsmen to sell their animals at low cost to enable them buy cereals (Thébaud \& Batterbury, 2001) and other household needs. This is where herdsmen along the Black Volta Basin blame the livestock owners for not living up to their obligations as agreed upon.

It is argued that governments need to take responsibility for resource allocation to pastoralists, and support user right (Thébaud \& Batterbury, 2001), in order to reduce adverse local decision powers (du Bois, 1994). Interestingly, in the Region, and perhaps in Ghana as a whole, pastoralists mostly come into the communities without the government permission, because there are multiple unapproved routes being used by these pastoralists. At best they negotiate with chiefs on the terms of agreement when they arrive. Thébaud and 
Batterbury (2001) posit that there is an inconsistent position/role of government regarding pastoralism in Niger. Similarly, in Ghana, the central government and its agencies have done little on the operational directive on the activities of pastoralists. Moreover, the Economic Community of West African States (ECOWAS) protocol on free movement across borders of member states also facilitates the influx of the Fulani herdsmen into the country. The MOFA is the main government agency responsible for providing veterinary services in the country. A decade ago, Tonah (2002) noted that the availability of veterinary services partly accounted for the influx of pastoralists into the savannah zone of Northern Ghana. However, this study established that access to veterinary services is a challenge and the pastoralists are now attracted by the presence of pastures, and water within the Black Volta and its tributaries. Although Bogale and Korf (2009) advanced that livestock is a source of food security, discussion with the MOFA revealed that the management of pastoralists activities in the study area has worsen food insecurity; due to the destruction of crops by livestock, bushfires resulting from the activities of herdsmen, overgrazing by livestock and reduction in livestock numbers.

As established by Tonah (2002), the study equally found that the key issue with the livestock owners and the hired pastoralists is trust and honesty. While the pastoralists blame livestock owners for not living up to their obligation, livestock owners do not trust pastoralists because they sell livestock and claim they (livestock) are lost. While the various actors blame one another for the causes of environmental degradation and water loss, the ripple effect rather are not selective. As indicated by President George Bush during the hurricane, "the storm didn't discriminate", it affected many people although it was argued that the most affected were the poor black (Sweeney, 2006:164).

\section{Conclusion}

Pastoralists' access to water and pasture, for both human and animal consumption, is a major constituent of their livelihoods. In the process of accessing water and pastures, there is a blame game. The blame is centred on environmental degradation, social insecurity/vices and food insecurity. The blame game is strong among actors in pastoralism and water rights while dialogue is minimal among them. Based on the major issues that the blame revolves around, the study supports the conclusion that the actors blame because blame is easy to do; what is hard to do is to change the process that puts them into a blaming circumstance (Hein, 1998). The blame game adversely affects collaboration and cooperation within and among the hierarchy of actors. The practice of pastoralism is not bad, because it has benefits to society. However, its practice needs to be managed and this requires cross-functional cooperation which is built on trust and respect. But these elements are weakened in a situation where the actors in pastoralism and water rights practice the Blame Game. Therefore, an unmanaged blame game is paralyzing, because when actors in an event blame each other, each tends to be defensive and neither of them gets to the actual issue. Although Hardin's model on open access is manifested in pastoralism in the region, the depletion of environmental resources coupled with other socio-economic vices posed by pastoralism has compelled those in higher authority to regulate access to pasturing. In other words, scarcity of resources is gradually limiting the relevance of open access in pastoralism.

Therefore, all actors in pastoralism and water rights need to stop swerving problems and rather adopt root cause analysis of the problems. That is, they do not have to run away from finding the fundamental cause of the problems posed by pastoralism. An enforcement of existing laws and other related legislations on environmental management is necessary because, as Molle (2004) posits, rights are meaningless without a way to enforce them, as vested in the state or the community. On the other hand, there is the need to establish and enforce rules and regulations (guidelines) for the utilization of water resources. But enforcing water rights requires effective monitoring (Meinzen-Dick \& Nkonya, 2005), and a cost effective way is to adopt community-based monitoring. The social insecurity that emerged in the study requires serious attention and as such all alien herdsmen and livestock owners need to be registered with the District Assembly. A key strategy is for the District Assembly to open registers at the sub-district levels to register herdsmen/livestock owners and issue Identification Cards to those registered. This will help regulate entry and exit of alien herdsmen.

\section{References}

Adger, W. N., Brown, K., \& Tompkins, E. L. (2005). The political economy of cross-scale networks in resource co-management. Ecology and Society, 10(2), 9.

Agrawal, A., \& Ostrom, E. (2001). Collective action, property rights, and decentralization in resource use in India and Nepal. Politics \& Society, 29(4), 485-514. http://dx.doi.org/10.1177/0032329201029004002

Bayer, W., Lossau, A. v., \& Feldmann, A. (2001). Smallholders and Community-Based Management of Farm Animal Genetic Resources. Paper presented at the Community-based Management of Animal Genetic Resources, Mbabane, Swaziland. 
Beyene, F., \& Korf, B. (2012). Unmaking the Commons: Collective Action, Property Rights, and Resource Appropriation among (Agro-) Pastoralists in Eastern Ethiopia. In E. Mwangi, H. Markelova \& R. Meinzen-Dick (Eds.), Collective Action and Property Rights for Poverty Reduction: Insights from Africa and Asia (pp. 304-327). USA: University of Pennsylvania Press.

Bird, J., Arriens, W. L., \& Von Custodio, D. (2007). Promoting Effective Water Management Policies and Practices (Phase 4).

Bogale, A., \& Korf, B. (2009). Resource entitlement and mobility of pastoralists in the Yerer and Daketa valleys, Eastern Ethiopia. Human Ecology, 37(4), 453-462. http://dx.doi.org/10.1007/s10745-009-9236-3

Bromley, D. W. (1991). Environment and economy: Property rights and public policy. Basil Blackwell Ltd.

Bruns, B. (2007). Irrigation water rights: options for pro - poor reform. Irrigation and Drainage, 56(2-3), 237-246. http://dx.doi.org/10.1002/ird.314

Burchi, S., \& D'Andrea, A. (2003). Preparing national regulations for water resources management: principles and practice (Vol. 80): FAO.

Ciriacy-Wantrup, S. V., \& Bishop, R. C. (1975). Common property as a concept in natural resources policy. Nat. Resources $J ., 15,713$.

Cousins, B. (1996). Conflict Management for Multiple Resource Users in Pastoralist and Agro - Pastoralist Contexts. IDS Bulletin, 27(3), 41-54. http://dx.doi.org/10.1111/j.1759-5436.1996.mp27003005.x

Dennis, V., \& Arriens, W. (2005). Understanding water rights and water allocation. Paper presented at the 1st NARBO Thematic Workshop on Water Rights and Water Allocation, Hanoi, Viet Nam.

du Bois, F. (1994). Water rights and the limits of environmental law. Journal of Environmental Law, 6(1), 73-84.

Dwyer, M. J., \& Istomin, K. V. (2008). Theories of nomadic movement: a new theoretical approach for understanding the movement decisions of Nenets and Komi reindeer herders. Human Ecology, 36(4), 521-533. http://dx.doi.org/10.1007/s10745-008-9169-2

Eguavoen, I., \& Spalthoff, D. (2008). Getting access right: human rights and household water rights in Ghana. Paper presented at the 13th World Water Congress.

Entsua-Mensah, M. (2001). Traditional management of water resources in West Africa. Conflict and cooperation related to international water resources: Historical perspectives, 49.

Fabusoro, E. (2009). Use of collective action for land accessibility among settled Fulani agro-pastoralists in southwest Nigeria. Sustainability Science, 4(2), 199-213. http://dx.doi.org/10.1007/s11625-009-0082-4

Feeny, D., Berkes, F., McCay, B. J., \& Acheson, J. M. (1990). The tragedy of the commons: twenty-two years later. Human Ecology, 18(1), 1-19. http://dx.doi.org/10.1007/BF00889070

Gomes, N. (2006). Access to water, pastoral resource management and pastoralists' livelihoods: Lessons learned from water development in selected areas of Eastern Africa (Kenya, Ethiopia, Somalia). FAO LSP WP, 26.

Hagedorn, K., Kirk, M., Korf, B., McCarthy, N., Ruth Meinzen-Dick, \& Swallow, B. (2012). Property Rights and Collective Action for Poverty Reduction: A Framework for Analysis. In E. Mwangi, H. Markelova \& R. Meinzen-Dick (Eds.), Collective Action and Property Rights for Poverty Reduction: Insights from Africa and Asia (pp. 25-48). USA: University of Pennsylvania Press.

Hein, F. (1998). The blame game. Software, IEEE, 15(6), 89-91. http://dx.doi.org/10.1109/52.730852

Hendrickson, D., Armon, J., \& Mearns, R. (1998). The Changing Nature of Conflict and Famine Vulnerability: The Case of Livestock Raiding in Turkana District, Kenya. Disasters, 22(3), 185-199. http://dx.doi.org/10.1111/1467-7717.00086

Hesse, C., \& MacGregor, J. (2006). Pastoralism: Drylands' Invisible Asset?: Drylands Programme, International Institute for Environment and Development.

Hogg, R. (1987). Development in Kenya: Drought, desertification and food scarcity. African Affairs, 86(342), 47-58.

Hood, C. (2010). The blame game: Spin, bureaucracy, and self-preservation in government. Princeton University Press. 
Kabudi, P. J. (2005). Challenges of legislating for water utilisation in rural Tanzania: drafting new laws. Paper presented at the International workshop on 'African Water Laws: Plural Legislative Frameworks for Rural Water Management in Africa, Johannesburg, South Africa.

Katjiua, M., \& Ward, D. (2007). Pastoralists' perceptions and realities of vegetation change and browse consumption in the northern Kalahari, Namibia. Journal of Arid Environments, 69(4), 716-730. http://dx.doi.org/10.1016/j.jaridenv.2006.11.010

Köhler-Rollefson, I. (2001). Community-Based Management of Animal Genetic Resources - with Special Reference to Pastoralists. Paper presented at the Community-based Management of Animal Genetic Resources, Mbabane, Swaziland.

Livingstone, I. (1986). The common property problem and pastoralist economic behavior. The Journal of Development Studies, 23(1), 5-19. http://dx.doi.org/10.1080/00220388608422016

MacCay, B. J., \& Acheson, J. M. (1987). The question of the commons: The culture and ecology of communal resources. University of Arizona Press.

McCabe, J. T. (1990). Turkana pastoralism: A case against the tragedy of the commons. Human Ecology, 18(1), 81-103. http://dx.doi.org/10.1007/BF00889073

Meinzen-Dick, R., \& Nkonya, L. (2005). Understanding legal pluralism in water rights: lessons from Africa and Asia. Paper presented at the International workshop on 'African Water Laws: Plural Legislative Frameworks for Rural Water Management in Africa, Johannesburg, South Africa.

Mensah, K. (1999). Water law, water rights and water supply (Africa). Ghana-study country report. Silsoe, Department for International Development, 28.

Molle, F. (2004). Defining water rights: by prescription or negotiation? Water Policy, 6(3), 207-227.

Nori, M., Taylor, M., \& Sensi, A. (2008). Browsing on fences: pastoral land rights, livelihoods and adaptation to climate change. IIED.

Oba, G., \& Lusigi, W. J. (1987). An overview of drought strategies and land use in African pastoral systems. Agricultural Administration Unit, Overseas Development Institute.

Omosa, E. K. (2005). The Impact of Water Conflicts on Pastoral Livelihoods. Winnipeg: International Institute for Sustainable Development.

Robinson, L. W., \& Berkes, F. (2011). Multi-level participation for building adaptive capacity: Formal agency-community interactions in northern Kenya. Global Environmental Change, 21(4), 1185-1194. http://dx.doi.org/10.1016/j.gloenvcha.2011.07.012

Scoones, I., \& Graham, O. (1994). New directions for pastoral development in Africa. Development in Practice, 4(3), 188-198. http://dx.doi.org/10.1080/096145249100077821

Sweeney, K. A. (2006). The blame game: Racialized responses to Hurricane Katrina. Du Bois Review, 3(01), 161-174. http://dx.doi.org/10.1017/S1742058X06060115

Thébaud, B., \& Batterbury, S. (2001). Sahel pastoralists: opportunism, struggle, conflict and negotiation. A case study from eastern Niger. Global Environmental Change, 11(1), 69-78. http://dx.doi.org/10.1016/S0959-3780(00)00046-7

Tonah, S. (2002). Fulani Pastoralists, Indigenous Farmers and the Contest for Land in Northern Ghana. Africa Spectrum, 37(1), 43-59.

Tonah, S. (2003). Integration or exclusion of Fulbe pastoralists in West Africa: a comparative analysis of interethnic relations, state and local policies in Ghana and Côte d'Ivoire. Journal of Modern African Studies, 91-114. http://dx.doi.org/10.1017/S0022278X02004160

Water Resources Commission Act, ACT 522. (1996).

Williamson, O. E. (1993). Transaction Cost Economics and Organisation Theory: From Chester Barnard to the Present and Beyond (Expanded Edition ed.). USA: Oxford University Press Inc.

Yin, R. K. (1994). Case Study Research: Design and Methods. Thousands Oaks: CA: Sage.

Yin, R. K. (Ed.). (2003). Case Study Research: Design and Methods (Third ed. Vol. 5). London: Sage Publications, Inc. 


\section{Copyrights}

Copyright for this article is retained by the author(s), with first publication rights granted to the journal.

This is an open-access article distributed under the terms and conditions of the Creative Commons Attribution license (http://creativecommons.org/licenses/by/3.0/). 